\title{
Effect of Population Density of Pseudomonas fluorescens on Production of 2,4-Diacetylphloroglucinol in the Rhizosphere of Wheat
}

\author{
Jos M. Raaijmakers, Robert F. Bonsall, and David M. Weller
}

First and third authors: U.S. Department of Agriculture, Agricultural Research Service; and second author: Department of Plant Pathology, Washington State University, Pullman, WA 99164-6430.

Accepted for publication 23 February 1999.

\begin{abstract}
Raaijmakers, J. M., Bonsall, R. F., and Weller, D. M. 1999. Effect of population density of Pseudomonas fluorescens on production of 2,4-diacetylphloroglucinol in the rhizosphere of wheat. Phytopathology 89:470-475.

The role of antibiotics in biological control of soilborne pathogens, and more generally in microbial antagonism in natural disease-suppressive soils, often has been questioned because of the indirect nature of the supporting evidence. In this study, a protocol for high pressure liquid chromatography/mass spectrometry is described that allowed specific identification and quantitation of the antibiotic 2,4-diacetylphloroglucinol (Phl) produced by naturally occurring fluorescent Pseudomonas spp. on roots

of wheat grown in a soil suppressive to take-all of wheat. These results provide, for the first time, biochemical support for the conclusion of previous work that Phl-producing fluorescent Pseudomonas spp. are key components of the natural biological control that operates in take-all-suppressive soils in Washington State. This study also demonstrates that the total amount of Phl produced on roots of wheat by P. fluorescens strain Q2-87, at densities ranging from approximately $10^{5}$ to $10^{7} \mathrm{CFU} / \mathrm{g}$ of root, is proportional to its rhizosphere population density and that $\mathrm{Phl}$ production per population unit is a constant $\left(0.62 \mathrm{ng} / 10^{5} \mathrm{CFU}\right)$. Thus, $\mathrm{Phl}$ production in the rhizosphere of wheat is strongly related to the ability of the introduced strain to colonize the roots.
\end{abstract}

Various mechanisms account for the ability of fluorescent Pseudomonas strains to control plant pathogens, including competition for iron and other nutrients, niche exclusion (35), induction of systemic resistance $(23,24)$, and production of antimicrobial metabolites (32). Our studies have focused on the role of the antibiotic 2,4-diacetylphloroglucinol $(\mathrm{Phl})$ in biological control of soilborne pathogens by fluorescent Pseudomonas spp. $(4,36)$. Phl is a phenolic metabolite with antibacterial, antifungal, anthelminthic, and phytotoxic properties (32). Genetic studies, modeled after Koch's postulates, demonstrated that $\mathrm{Phl}$ produced by fluorescent Pseudomonas strains plays a major role in the suppression of various soilborne plant pathogens $(7,11,28,34)$. Numerous strains of Phl-producing Pseudomonas spp. were isolated from soils from diverse geographical regions and were readily isolated from roots of plants grown in soils that are naturally suppressive to diseases such as black root rot of tobacco and Fusarium wilt of tomato (12). Moreover, Phl-producing fluorescent Pseudomonas spp. were highly enriched in soils that are suppressive to take-all of wheat and are key components of the natural biological control that operates in these soils $(25,26)$.

The significance of antibiotics in biological control, and more generally in microbial antagonism in natural disease-suppressive soils, often has been questioned in the past because of the indirect nature of the supporting evidence and the perceived constraints to antibiotic production in soil environments $(9,37)$. Because of the biotic and abiotic complexity of soils, there are several inherent

Corresponding author: R. F. Bonsall; E-mail address: bonsall@wsu.edu

Mention of a trademark or proprietary product does not constitute a guarantee or warranty of the product by the U.S. Department of Agriculture and does not imply approval to the exclusion of other products that may be suitable.

Publication no. P-1999-0330-01R

This article is in the public domain and not copyrightable. It may be freely reprinted with customary crediting of the source. The American Phytopathological Society, 1999. difficulties in detecting antibiotics produced by microorganisms in soil and rhizosphere environments. Depending on the nature of the metabolite, recovery and detection may be hampered by chemical instability of the compound, irreversible binding to soil colloids or organic matter, or microbial decomposition (31). Sensitive methods have been developed by which the expression of specific traits of biocontrol agents, such as antibiotic production, can be measured in natural environments. One approach involves the use of reporter gene systems $(17,18)$. One of the disadvantages of this approach in studying in situ antibiotic production is that it does not provide an accurate measure of the amount of the antibiotic produced. Bioanalytical techniques like thin layer chromatography and high pressure liquid chromatography (HPLC) are now being used to detect and quantify antibiotics produced by microorganisms in situ (31). The versatility, resolving capability, and quantitative accuracy of HPLC make it one of the best direct methods to study the production of antibiotics in situ. HPLC has been successfully used for the in situ detection of a variety of antibiotics including phenazine-1-carboxylic acid (33), herbicolin A (13), pyrrolnitrin (14), gliotoxin (19), and Phl $(2,11)$.

To further elucidate the role of introduced and naturally occurring Phl-producing Pseudomonas spp. in biological control of soilborne plant pathogens and microbial antagonism in natural disease-suppressive soils, we developed a protocol for HPLC/mass spectrometry (MS) to identify and quantify Phl produced on roots of wheat plants grown in raw soil. We then describe the effect of population density on production of $\mathrm{Phl}$ in situ by P. fluorescens Q2-87. Finally, we demonstrate, for the first time, that $\mathrm{Phl}$ is produced by naturally occurring fluorescent Pseudomonas spp. on roots of wheat grown in a soil that is suppressive to take-all of wheat.

\section{MATERIALS AND METHODS}

Bacterial strains and culture conditions. $P$. fluorescens strains Q2-87 and Q8r1-96 both produce the antibiotic Phl. Strains Q2-87 and Q8r1-96 were isolated in 1987 and 1996, respectively, from wheat grown in soil collected from an agricultural field near 
Quincy, WA $(22,25)$. Spontaneous rifampin-resistant derivatives of strains Q2-87 and Q8r1-96 were used in the experiments. Both strains were cultured on King's medium B (KMB) agar (15) supplemented with rifampin $\left(100 \mu \mathrm{g} \mathrm{ml}^{-1}\right)$. Naturally occurring fluorescent Pseudomonas spp. were isolated from wheat roots on KMB agar supplemented with cycloheximide $\left(100 \mu \mathrm{g} \mathrm{ml}^{-1}\right)$, chloramphenicol $\left(13 \mu \mathrm{g} \mathrm{ml}^{-1}\right)$, and ampicillin $\left(40 \mu \mathrm{g} \mathrm{ml}^{-1}\right)\left(\mathrm{KMB}^{+}\right)$(29).

Soils. Soils were collected from two sites near Quincy, WA. Soil from an agricultural field, designated Quincy take-all decline (TAD), is suppressive to take-all of wheat. In 1980, the Quincy TAD field had been cropped continuously to wheat for 22 years; between 1980 and 1995, other crops besides wheat also were grown. A noncropped virgin soil, designated Quincy virgin, was covered by native vegetation such as sagebrush and bunchgrass and was located near the Quincy TAD field. The Quincy virgin soil is conducive to take-all of wheat. The soils were collected in March 1995 from the upper $30 \mathrm{~cm}$ of the soil profile, air-dried for 1 week, and passed through a $0.5-\mathrm{cm}-\mathrm{mesh}$ screen prior to use. Their physical and chemical properties were determined by the Analytical Sciences Laboratory, University of Idaho, and described previously $(26,36)$.

Seed treatment. Wheat seeds (cv. Penewawa) were treated with an aqueous solution of $1 \%$ methyl cellulose (Sigma Chemical Co., St. Louis) or with suspensions of strains Q2-87 or Q8r1-96 in 1\% methyl cellulose. The coated seeds were air-dried for $5 \mathrm{~h}$ in a laminar flow cabinet. Final densities of Q2-87 were approximately $10^{2}, 10^{3}, 10^{4}, 10^{5}$, or $10^{6} \mathrm{CFU}$ per seed, as determined by dilution plating on $\mathrm{KMB}^{+}$supplemented with rifampin $\left(100 \mu \mathrm{g} \mathrm{ml}^{-1}\right)$. The final density of Q8r1-96 was approximately $10^{5} \mathrm{CFU}$ per seed.

Plant cultivation. Approximately 25 wheat seeds were sown in square PVC pots $(8 \mathrm{~cm}$ high, $7.5 \mathrm{~cm}$ wide) containing $200 \mathrm{~g}$ of raw soil after $50 \mathrm{ml}$ of water supplemented with metalaxyl (Novartis Crop Protection, Greensboro, NC) was added at $2.5 \mathrm{mg}$ active ingredient per $\mathrm{ml}$ to control Pythium root rot. A 1-cm layer of soil was spread on top of the seeds. Plants were grown in a controlled-environment chamber at $16^{\circ} \mathrm{C}$ with a 12 -h photoperiod. Pots received $50 \mathrm{ml}$ of dilute $(2: 3$, vol/vol) Hoaglund's solution (macroelements only) twice a week. After 3 weeks of growth, the plants were harvested and loosely adhering soil was removed from the roots by gently shaking the plants. The root systems were excised and stored overnight in petri dishes at $4^{\circ} \mathrm{C}$ prior to the isolation of bacteria and the extraction of Phl. Each treatment was replicated two to four times, and five pots were used for each replicate.

Isolation of Phl-producing Pseudomonas spp. from roots of wheat. One gram of roots and associated rhizosphere soil harvested from each pot was suspended in $5.0 \mathrm{ml}$ of sterile water and shaken vigorously for $1 \mathrm{~min}$ on a Vortex mixer. The samples were subsequently sonicated in an ultrasonic cleaner (Bransonic 521; Branson Cleaning Equipment Co., Shelton, CT) for $1 \mathrm{~min}$, and then serial dilutions of the root wash were plated onto $\mathrm{KMB}^{+}$plus rifampin to determine the population density of Q2-87 or Q8r1-96. To determine the population density of naturally occurring Phl-producing fluorescent Pseudomonas spp., root washes obtained from wheat plants grown in Quincy virgin and Quincy TAD soils were plated onto $\mathrm{KMB}^{+}$. Plates were incubated at $25^{\circ} \mathrm{C}$ and colonies were enumerated after $48 \mathrm{~h}$. Colonies of fluorescent Pseudomonas spp. were differentiated from nonfluorescent colonies under UV light (wavelength $366 \mathrm{~nm}$ ). The number of fluorescent Pseudomonas spp. that harbor the genes for Phl was determined by colony hybridization followed by polymerase chain reaction (PCR) analysis (26).

Colony hybridization and PCR analysis. Transfer of bacterial colonies to Hybond- $\mathrm{N}^{+}$nylon membranes (Amersham International, Little Chalfont, United Kingdom) was performed by standard methods (27). After air-drying, the membranes were baked for $1 \mathrm{~h}$ at $80^{\circ} \mathrm{C}$ in a vacuum oven. To remove bacterial cell debris, the membranes were washed for $1.5 \mathrm{~h}$ at $42^{\circ} \mathrm{C}$ in a solution containing $2 \times$ SSPE (20 mM NaH${ }_{2} \mathrm{PO}_{4}$ [pH 7.4], $0.36 \mathrm{M} \mathrm{NaCl}$, and $2 \mathrm{mM}$ EDTA), $0.1 \%$ sodium dodecyl sulfate (SDS), and pronase $\left(100 \mu \mathrm{g} \mathrm{ml}^{-1}\right)$ and washed again for $1 \mathrm{~h}$ at $56^{\circ} \mathrm{C}$ in $2 \times \mathrm{SSPE}-0.1 \%$ SDS. Hybridizations were performed under high stringent conditions by standard methods (27). The Phl probe consisted of a 745-base pair (bp) DNA fragment amplified by PCR from Phl-producing strain P. fluorescens Q2-87 (26) and was generated by random-primed labeling using the nonradioactive digoxigenin system (Boehringer $\mathrm{GmbH}$, Mannheim, Germany). The hybridized probe was immunodetected with anti-digoxigenin-AP-Fab fragments, and Phl-positive colonies were visualized with the calorimetric substrates nitroblue tetrazolium salt and 5-bromo-4-chloro-3-indolylphosphate, according to protocols provided by the supplier. The lower limit of detection for indigenous Phl-producing Pseudomonas spp. was $10^{4} \mathrm{CFU} \mathrm{g}{ }^{-1}$ fresh weight of root (26). Positive colonies of fluorescent Pseudomonas strains were isolated and purified on KMB agar plates. PCR analysis of the isolated colonies was performed as a quality check of the colony hybridization. The oligonucleotide primers Phl2a and Phl2b were developed from sequences within $P h l \mathrm{D}$, one of the six genes in the Phl biosynthetic locus of $P$. fluorescens Q2-87 (GenBank accession no. U41818). Primers Phl2a and $\mathrm{Phl} 2 \mathrm{~b}$ were synthesized by Operon Technologies Inc. (Alameda, CA) and yielded a 745-bp fragment. DNA isolation by cell lysis and PCR amplification was carried out according to the methods described by Raaijmakers et al. (26).

Antibiotic extraction from roots of wheat grown in natural soil. Phl was isolated from roots of wheat according to the method described by Bonsall et al. (2). Thirty grams of wheat roots with adhering rhizosphere soil, without remnants of seeds and obtained from approximately 80 to 100 plants, was mixed in a $250-\mathrm{ml}$ flask with $40 \mathrm{ml}$ of $80 \%$ acetone acidified to $\mathrm{pH} 2.0$ with $10 \%$ trifluoroacetic acid (TFA) and then shaken (200 rpm) for $2 \mathrm{~h}$ at room temperature. Samples were subsequently filtered (Whatman no. 1; Whatman International, Ltd., Maidstone, England) through a Buchner funnel (Coors, Golden, $\mathrm{CO}$ ), and the filtrate was centrifuged at $12,400 \times g$ for $30 \mathrm{~min}$ at $4^{\circ} \mathrm{C}$ to remove small soil particles. The supernatant was evaporated to a volume of $8 \mathrm{ml}$, acidified to $\mathrm{pH}$ 2.0 with $10 \%$ TFA, extracted twice with $10 \mathrm{ml}$ of ethylacetate, and evaporated to dryness. Extracts were suspended in $1 \mathrm{ml}$ of $35 \%$ acetonitrile $(\mathrm{ACN})$ and $0.1 \%$ TFA and then centrifuged in an Eppendorf 5415 centrifuge (Brinkmann Instruments, Inc., Westbury, $\mathrm{NY}$ ) at $16,000 \times g$ for $20 \mathrm{~min}$ at $4^{\circ} \mathrm{C}$ prior to separation and identification by HPLC and MS. The extraction efficiency of Phl was approximately $60 \%$ (2).

HPLC photodiode array (PDA) spectroscopy. The Waters HPLC system (Waters Corporation, Milford, MA) consisted of a 717 Plus autosampler, 600E solvent delivery system, 600 controller, and 996 PDA detector. The HPLC protocol described by Bonsall et al. (2) was modified as follows. Root extracts were fractionated by $\mathrm{C}_{18}$ reverse-phase HPLC (Waters symmetry column, $3.9 \times 150 \mathrm{~mm}$; Waters Corporation) with 50- to 200- $\mu$ l sample injections. Solvent conditions included a flow rate of $0.5 \mathrm{ml} / \mathrm{min}$ with a 2 -min initialization at $10 \% \mathrm{ACN}-0.1 \%$ TFA, followed by a 20 min gradient to $100 \%$ ACN-0.1\% TFA using Waters curve profile \#5 (Waters Corporation). HPLC gradient profiles were monitored at 270 and $330 \mathrm{~nm}$, which represent the peak maxima of $\mathrm{Phl}$ in the designated solvent system. A seven-point standard curve used for quantification was generated by spiking known concentrations of pure $\mathrm{Phl}$ into root samples $(30 \mathrm{~g})$ collected from wheat grown in Quincy virgin soil prior to the extraction procedure described above. A highly significant linear relationship was found for the standard curve $\left(\mathrm{Phl}=0.00156 \times A, r^{2}=0.99, P<0.0001\right)$, in which $\mathrm{Phl}$ represents the total amount of $\mathrm{Phl}$ (ng) and $A$ represents the area of the $\mathrm{Phl}$ peak. The lowest amount of Phl extractable from the rhizosphere was $200 \mathrm{ng}$. For detection of $\mathrm{Phl}$ produced by relatively low population densities of introduced or resident Phl-producing Pseudomonas spp. (approximately $10^{5} \mathrm{CFU} / \mathrm{g}$ of root), two replicate samples were pooled.

MS. In a mass spectrometer, molecules of a compound are ionized to give the parent molecular weight ion (the actual molecular 
weight of the compound) and a series of fragment ions. Consequently, mass spectra show a series of peaks corresponding to the mass $(m)$ to charge $(e)$ ratio values ( $m / e$ values) of the positive ions produced from the compound. The structure of the compound can be deduced from this fragmentation pattern either by library matching (e.g., Wiley library, John Wiley \& Sons, Inc., New York) or by spectral interpretation. The Waters Integrity LC-MS system (Waters Corporation) used in this study consisted of an Alliance 2690 separation module with a 996 PDA detector and an electron ionization Thermabeam mass detector (TMD) (Waters Corporation, Milford, MA). Root extracts were fractionated by $\mathrm{C}_{18}$ reverse-phase HPLC with 100- $\mu$ l sample injections as described above. Solvent conditions included a flow rate of $0.35 \mathrm{ml} / \mathrm{min}$ with a 2-min initialization at $10 \% \mathrm{ACN}-2.0 \%$ acetic acid, followed by a 20 -min linear gradient to $100 \%$ ACN-2.0\% acetic acid. The TMD conditions included a helium flow rate of 15 psi with the temperatures of the ion source, expansion region, and nebulizer set at 220,80 , and $84^{\circ} \mathrm{C}$, respectively. TMD chromatograms were monitored at a total ion current of 170-355 m/e. The detection limit of $\mathrm{Phl}$ for electron ionization involving MS was $200 \mathrm{ng}$.

Statistical analysis. The experiments described in this study were performed at least twice. Regression analyses (SAS release 6.11; SAS Institute Inc., Cary, NC) were performed to determine the relationship between (i) rhizosphere population densities of Q2-87 and in situ production of Phl, and (ii) rhizosphere population densities of Q2-87 and the amount of $\mathrm{Phl}$ produced per population unit $\left(10^{5} \mathrm{CFU}\right)$. In all regression analyses, variables and intercepts were tested for differences from zero by performing $t$ tests $(\alpha=0.05)$. When the intercepts were not significantly different from zero, regressions were forced through the origin. The probability based match (PBM) algorithm was used in MS to determine the percent match between the submitted spectrum and the library spectrum (e.g., Wiley library, John Wiley \& Sons, Inc.). Differences between treatments in population densities and

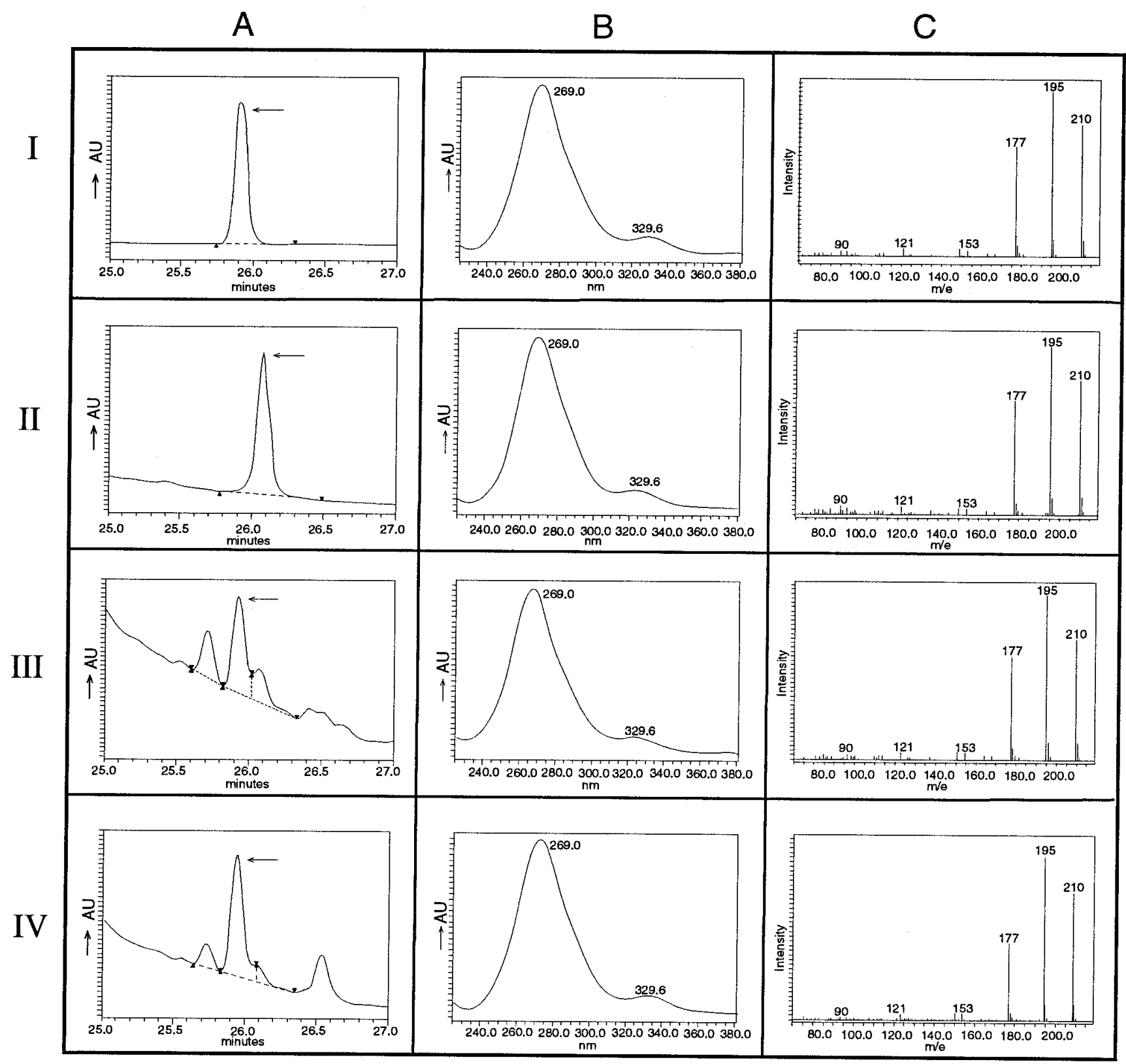

Fig. 1. High pressure liquid chromatography (HPLC) chromatograms and electron ionization mass spectrum of 2,4-diacetylphloroglucinol (Phl). I, Pure Phl; II, pure Phl spiked into extracts of root samples collected from nontreated wheat grown in raw Quincy virgin soil; III, extracts from root samples collected from wheat treated with strain Q8r1-96; and IV, extracts from root samples collected from wheat treated with strain Q2-87. A, HPLC chromatograms, dotted lines, and arrowheads indicate the area of the Phl peak; $\mathbf{B}$, photodiode array UV spectra of Phl for chromatogram peak shown in $\mathbf{A}$ (indicated with an arrow); and $\mathbf{C}$, electron ionization mass spectra of Phl for chromatogram peak shown in A (indicated with an arrow). 
amounts of $\mathrm{Phl}$ produced in situ were determined by analysis of variance followed by Tukey's studentized range test (SAS release 6.11; SAS Institute Inc.). When data were not normally distributed, differences between treatments were analyzed by Wilcoxon rank-sum test $(\alpha=0.05)$.

\section{RESULTS}

Identification of Phl by HPLC/MS. HPLC/MS analysis was performed on four different samples: (i) pure $\mathrm{Phl}$, (ii) pure $\mathrm{Phl}$ spiked into extracts of root samples collected from nontreated wheat grown in raw Quincy virgin soil, (iii) extracts of root samples collected from wheat treated with Phl-producing strain $P$. fluorescens Q8r1-96, and (iv) extracts of root samples collected from wheat treated with Phl-producing strain P. fluorescens Q2-87 (Fig. 1). The HPLC chromatograms showed that peaks from all four samples elute at retention times ranging from $25 \mathrm{~min}$ to $26.5 \mathrm{~min}$, the same area where pure $\mathrm{Phl}$ elutes under the given conditions (Fig. 1 A.I to A.IV). Because the peak maxima of 270 and $330 \mathrm{~nm}$ are characteristic of Phl in the specified solvent mixture (2), spectral analysis of the peaks by PDA spectroscopy allowed a positive identification of the Phl peak in all four chromatograms including those of the root extracts collected from wheat treated with either Q8r1-96 or Q2-87 (Fig. 1 B.I to B.IV). Phl was not detected in root extracts collected from nontreated wheat grown in raw Quincy virgin soil (data not shown). Subsequent MS showed that the mass spectrum of pure $\mathrm{Phl}$ is characterized by three intense peaks with $m / e$ values of 210, 195, and 177 (Fig. 1 C.I to C.IV). The highest mass peak of 210 is the parent molecular ion $(\mathrm{M}(+))$ and represents the molecular weight of Phl. The peak at $m / e$ 195 is most likely due to a neutral fragment loss of $\cdot \mathrm{CH}_{3}(\mathrm{M}(+)-15$ at $\mathrm{m} / \mathrm{e}=$ 210), whereas the peak at $m / e 177$ corresponds to a neutral fragment loss of $\cdot \mathrm{H}_{2} \mathrm{O}+\cdot \mathrm{CH}_{3}(\mathrm{M}(+)-33$ at $m / e=210)$ from the parent molecular ion. In addition to these three major peaks, the mass spectrum of $\mathrm{Phl}$ also is characterized by three minor peaks with $m / e$ values of 153, 121, and 90. PBM of the derived mass spec-

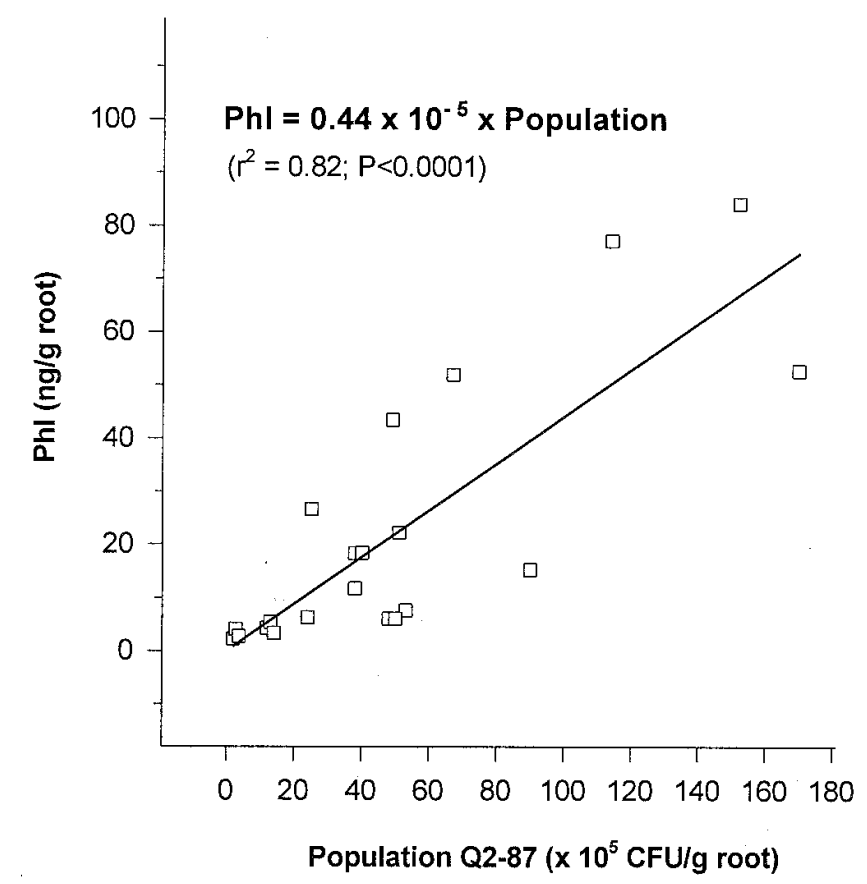

Fig. 2. Relationship between the rhizosphere population density of Pseudomonas fluorescens Q2-87 and the total amount of the antibiotic Phl produced on roots of wheat grown in raw Quincy virgin soil. Wheat seeds were treated with Q2-87 at densities of approximately $10^{2}, 10^{3}, 10^{4}, 10^{5}$, and $10^{6} \mathrm{CFU}$ per seed in order to achieve a range of population densities in the rhizosphere. Results of four experiments are shown, representing a total of 22 replicates; five pots were used for each replicate. trum of pure Phl with the Wiley library spectrum showed a 93\% fit. Identical mass spectra were obtained from root extracts spiked with pure $\mathrm{Phl}(79 \%$ fit) and from root extracts collected from wheat treated with either Q8r1-96 (83\% fit) or Q2-87 (95\% fit). These results demonstrate that, in addition to HPLC, MS enables positive identification of $\mathrm{Phl}$ produced by fluorescent Pseudomonas strains introduced onto roots of wheat grown in a raw soil.

Effect of population density on Phl production by $P$. fluorescens Q2-87. Dose-response studies were performed to determine the relationship between rhizosphere population densities of Q2-87 and in situ production of Phl. Wheat seeds treated with different densities of Q2-87 were sown in raw Quincy virgin soil, and rhizosphere population densities of Q2-87 and Phl production were determined after 3 weeks of plant growth. Regression analysis showed a highly significant linear relationship between the total amount of Phl produced on roots of wheat and the rhizosphere population density of Q2-87 (Fig. 2). At population densities of Q2-87 smaller than $10^{5} \mathrm{CFU} / \mathrm{g}$ fresh weight of root, $\mathrm{Phl}$ could not be detected. Logarithmic and quadratic relationships between the total amount of $\mathrm{Phl}$ and the rhizosphere population density of Q2-87 were considerably less significant $\left(r^{2}=0.45\right.$ and 0.59 , respectively) than the linear relationship shown in Figure 2. Data analysis also demonstrated that the amount of $\mathrm{Phl}$ produced per population unit $\left(10^{5} \mathrm{CFU}\right)$ was independent of the rhizosphere population density of Q2-87 $\left(r^{2}=0.07, P=0.24\right)$ and averaged $0.62 \mathrm{ng} / 10^{5} \mathrm{CFU}$ (Fig. 3). These results indicate that, for population densities of Q2-87 ranging from approximately $10^{5}$ to $10^{7} \mathrm{CFU} / \mathrm{g}$ fresh weight of root, the total amount of Phl produced on roots of wheat is proportional to the rhizosphere population density, and Phl production per population unit is a constant.

Phl production on roots of wheat grown in a take-all decline soil. Recently, we demonstrated that naturally occurring Phl-producing fluorescent Pseudomonas spp. were highly enriched in take-all-suppressive soils from Washington State and are key components of the specific suppression that operates in these soils (25, 26). To provide biochemical support for the role of $\mathrm{Phl}$ in take-all decline, Phl production and population densities of naturally occurring Phl-producing Pseudomonas spp. were determined on roots

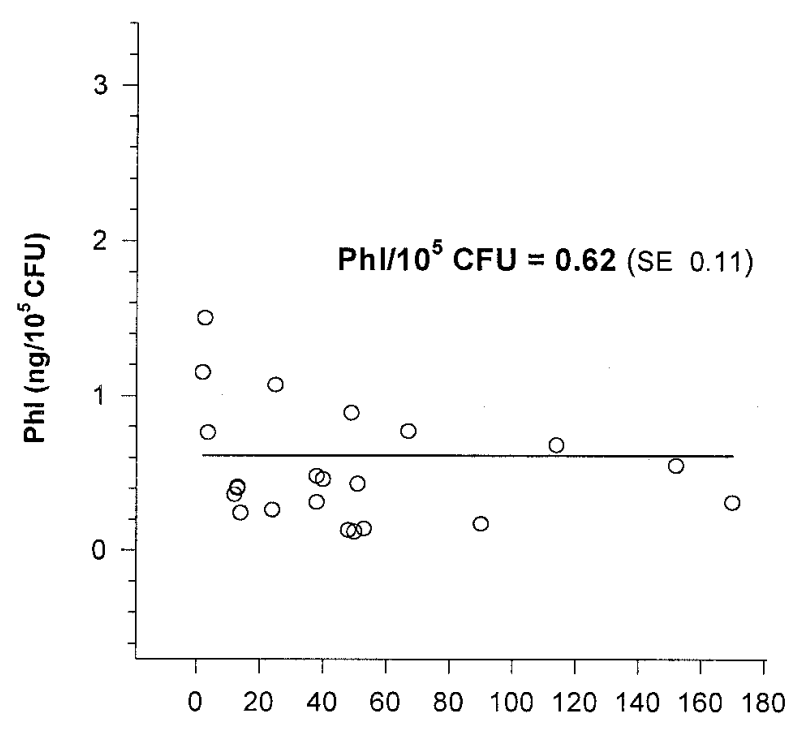

Population Q2-87 (x 10 $\mathrm{CFU/g}$ root)

Fig. 3. Relationship between the rhizosphere population density of Pseudomonas fluorescens Q2-87 and the amount of Phl produced per population unit $\left(10^{5} \mathrm{CFU}\right)$. Wheat seeds were treated with Q2-87 at densities of approximately $10^{2}, 10^{3}, 10^{4}, 10^{5}$, and $10^{6} \mathrm{CFU}$ per seed in order to achieve a range of population densities in the rhizosphere. Results of four experiments are shown, representing a total of 22 replicates; five pots were used for each replicate. $\mathrm{SE}=$ standard error. 
of wheat plants grown for 3 weeks in Quincy TAD soil and in Quincy virgin soil (Table 1). Neither Phl-producing Pseudomonas spp. nor Phl were detected on roots of wheat grown in raw Quincy virgin soil, which is conducive to take-all of wheat. In contrast, indigenous Phl-producing fluorescent Pseudomonas spp. were present on roots of wheat grown in the Quincy TAD soil at a density of $4.3 \times 10^{6} \mathrm{CFU} / \mathrm{g}$ fresh weight of root, and the total amount of $\mathrm{Phl}$ detected was $19.1 \mathrm{ng} / \mathrm{g}$ fresh weight of root. The amount of $\mathrm{Phl}$ detected on roots of wheat treated with strain Q8r1-96, which originally was isolated from the Quincy TAD soil, was $254.5 \mathrm{ng} / \mathrm{g}$ fresh weight of root. Given the differences in population densities, however, no significant difference was observed in $\mathrm{Phl}$ production per population unit between Quincy TAD and the Q8r1-96 treatment. Moreover, Phl production per population unit $\left(10^{5} \mathrm{CFU}\right)$ in Quincy TAD and the Q8r1-96 treatment was also similar to the average value reported earlier for strain Q2-87 (Fig. 3).

\section{DISCUSSION}

To detect and quantify Phl and other antibiotics by HPLC, the extracted and separated compounds need to be positively identified. Identification of $\mathrm{Phl}$ and other compounds on the basis of their retention time is not sufficient. Spectral analysis by PDA detectors is required to provide the necessary information about peak homogeneity and identity. In most cases, spectral analysis over a range of wavelengths will provide sufficient information on the compound. However, spectral analysis may have its limits. Determining the identity of compounds in overlapping peaks may be difficult if the spectra of the compounds are similar and the peaks are poorly resolved (5). Also, deviations in the spectral characteristics of the compound can be induced by volatilization of the solvents and may occur after derivitization. This study demonstrates that, in addition to HPLC, MS provides a means to confirm the identity of antibiotics produced by fluorescent Pseudomonas spp. on roots of plants grown in natural soils.

Fluorescent Pseudomonas spp. have been implicated in the specific suppression that operates in soils that are naturally suppressive to certain soilborne pathogens $(1,3,16)$. The results presented in this study demonstrate, for the first time, that the antibiotic Phl is produced by naturally occurring fluorescent Pseudomonas spp. on roots of wheat grown in a take-all-suppressive soil and not in a complementary take-all-conducive soil. The amount of Phl produced per population unit on roots of wheat grown in the Quincy TAD soil was very similar to the amounts produced by Pseudo-

TABLE 1. Production of 2,4-diacetylphloroglucinol $(\mathrm{Phl})$ and population densities of introduced and naturally occurring Phl-producing fluorescent Pseudomonas spp. in Quincy virgin and Quincy take-all decline (TAD) soils ${ }^{\mathrm{u}}$

\begin{tabular}{lccc}
\hline Treatment & $\begin{array}{c}\text { Phl } \\
\text { (ng/g of root) }\end{array}$ & $\begin{array}{c}\text { Population }^{\mathrm{v}} \\
\text { (CFU/g of root) }\end{array}$ & $\begin{array}{c}\text { Phl/population } \\
\text { (ng/105 CFU) }\end{array}$ \\
\hline Quincy virgin & $\mathrm{nd}^{\mathrm{w}}$ & $\mathrm{nd}$ & $\mathrm{nd}$ \\
Quincy virgin + Q8r1-96 & $254.5 \mathrm{a}^{\mathrm{y}}$ & $4.2 \times 10^{7} \mathrm{a}^{\mathrm{z}}$ & $0.56 \mathrm{a}^{\mathrm{z}}$ \\
Quincy TAD & $19.1 \mathrm{~b}$ & $4.3 \times 10^{6} \mathrm{~b}$ & $0.48 \mathrm{a}$ \\
\hline
\end{tabular}

u Average values of two experiments are shown; in each experiment, treatments were replicated two times, and five pots were used for each replicate.

v To isolate Phl-producing Pseudomonas spp., one gram of roots plus adhering rhizosphere soil was suspended in $5.0 \mathrm{ml}$ of sterile water, shaken on a Vortex mixer, sonicated, and then dilution-plated. Strain Q8r1-96 was enumerated on $\mathrm{KMB}^{+}$plus rifampin. Indigenous Phl-producing Pseudomonas spp. were isolated on $\mathrm{KMB}^{+}$and enumerated by colony hybridization followed by polymerase chain reaction analysis as described in text.

${ }^{\mathrm{w}} \mathrm{nd}=$ Neither Phl nor populations of Phl-producing Pseudomonas spp. were detected (detection limit was $10^{4} \mathrm{CFU} / \mathrm{g}$ of root).

${ }^{x}$ P. fluorescens strain Q8r1-96 was applied to wheat seeds at a density of approximately $10^{5} \mathrm{CFU}$ per seed.

${ }^{y}$ Within the column, different letters indicate a statistically significant difference (Wilcoxon rank-sum test, $\alpha=0.05$ ).

${ }^{\mathrm{z}}$ Within the column, different letters indicate a statistically significant difference (Tukey's studentized range test, $\alpha=0.05$ ). monas strains Q2-87 and Q8r1-96, two strains that were originally isolated from Quincy TAD soil and that provide significant control of take-all of wheat $(22,25,34)$. These biochemical data support the conclusion of previous work that Phl-producing fluorescent Pseudomonas spp. are key components of the natural biological control that operates in take-all-suppressive soils in Washington State (25).

The natural environments in which either introduced or naturally occurring antibiotic-producing Pseudomonas spp. function are subjected to changes in abiotic and biotic conditions. Several abiotic factors such as oxygen, temperature, specific carbon and nitrogen sources, and microelements have been identified or proposed to influence in situ antibiotic production by fluorescent Pseudomonas spp. $(6,10,21,28,30)$. Among the biotic factors that may play a determinative role in the regulation of antibiotic production are the plant host $(8,20)$, the pathogen $(6)$, the indigenous microflora (39), and the cell density of the producing strain $(38,40)$. This study demonstrates that the total amount of $\mathrm{Phl}$ produced on roots of wheat by $P$. fluorescens Q2-87, at densities ranging from approximately $10^{5}$ to $10^{7} \mathrm{CFU} / \mathrm{g}$ of root, is proportional to its rhizosphere population density (Fig. 2) and that Phl production per population unit is a constant (Fig. 3). These results indicate that $\mathrm{Phl}$ production in the rhizosphere of wheat is related strongly to the ability of the introduced strain to colonize the roots. The results also suggest that within the given range of population densities there is no abiotic or biotic limitation for P. fluorescens Q2-87 to produce the antibiotic or that certain limitations apply equally to the whole population range. It should be emphasized, however, that the amount of Phl reported for the different rhizosphere population densities of strain Q2-87 are average values for whole root systems, sampled at 0 to $8 \mathrm{~cm}$ from the stem base and harvested after 3 weeks of plant growth; therefore, it does not take into account spatial-temporal colonization and production patterns. The time and place of antibiotic production needs to be considered with respect to the efficacy of biological control of several plant pathogens. For example, an antibiotic may reach threshold concentrations for activity within certain microsites while remaining below this threshold level at other sites where pathogen infection also occurs. This may offer an explanation for the observation that population densities of $P$. fluorescens Q2-87 higher than the threshold density (approximately $2 \times 10^{5} \mathrm{CFU} / \mathrm{g}$ root) required to control take-all of wheat did not significantly improve the level of suppression (25).

The relationship between the population density of $P$. fluorescens Q2-87 and Phl production in the rhizosphere of wheat described in this study should not be confused with cell density-dependent regulation of antibiotic biosynthetic genes. Cell density-dependent regulation through the production of $\mathrm{N}$-acyl-homoserine lactones (AHLs) has been demonstrated for a variety of microorganisms, including phenazine-producing Pseudomonas strain 30-84 (38), and is referred to as autoinduction or quorum sensing. Whether the expression of the Phl biosynthetic locus in strain Q2-87 and other fluorescent Pseudomonas strains is AHL-mediated is yet unclear and is currently under investigation.

\section{ACKNOWLEDGMENTS}

This research was supported by grant 94-37107-0439 from the U.S. Department of Agriculture, Office of Grants and Program Systems, National Research Initiative, Competitive Grants Program. We thank K. Hays, S. E. Kalloger, and K. L. Schroeder for their technical support.

\section{LITERATURE CITED}

1. Alabouvette, C., Lemanceau, P., and Steinberg, C. 1993. Recent advances in the biological control of Fusarium wilts. Pestic. Sci. 37:365-373.

2. Bonsall, R. F., Weller, D. M., and Thomashow, L. S. 1997. Quantification of 2,4-diacetylphloroglucinol produced by fluorescent Pseudomonas spp. in vitro and in the rhizosphere of wheat. Appl. Environ. Microbiol. 
63:951-955.

3. Cook, R. J., and Baker, K. F. 1983. The Nature and Practice of Biological Control of Plant Pathogens. The American Phytopathological Society, St. Paul, MN.

4. Cook, R. J., Thomashow, L. S., Weller, D. M., Fujimoto, D., Mazzola, M., Bangera, G., and Kim, D.-S. 1995. Molecular mechanisms of defense by rhizobacteria against root disease. Proc. Natl. Acad. Sci. U.S.A. 92:4197-4201.

5. Dorschel, C. 1997. The role of particle-beam LC-MS in separation development. Liq. Chromatogr. Gas Chromatogr. 15:950-959.

6. Duffy, B. K., and Défago, G. 1997. Zinc improves biocontrol of Fusarium crown and root rot of tomato by Pseudomonas fluorescens and represses the production of pathogen metabolites inhibitory to bacterial antibiotic biosynthesis. Phytopathology 87:1250-1257.

7. Fenton, A. M., Stephens, P. M., Crowley, J., O'Callaghan, M., and O'Gara, F. 1992. Exploitation of gene(s) involved in 2,4-diacetylphloroglucinol biosynthesis to confer a new biocontrol capability to a Pseudomonas strain. Appl. Environ. Microbiol. 58:3873-3878.

8. Georgakopoulos, D., Hendson, M., Panopoulos, N. J., and Schroth, M. N. 1994. Analysis of expression of a phenazine biosynthetic locus of Pseudomonas aureofaciens PGS12 on seeds with a mutant carrying a phenazine biosynthesis locus-ice nucleation reporter gene fusion. Appl. Environ. Microbiol. 60:4573-4579.

9. Gotlieb, D. 1976. The production and role of antibiotics in soil. J. Antibiot. 29:987-1000.

10. Howie, W. J., and Suslow, T. V. 1991. Role of antibiotic biosynthesis in the inhibition of Pythium ultimum in the cotton spermosphere and rhizosphere by Pseudomonas fluorescens. Mol. Plant-Microbe Interact. 4: 393-399.

11. Keel, C., Schnider, U., Maurhofer, M., Voisard, C., Laville, J., Burger, U., Wirthner, P., Haas, D., and Défago, G. 1992. Suppression of root diseases by Pseudomonas fluorescens CHA0: Importance of the bacterial secondary metabolite 2,4-diacetylphloroglucinol. Mol. Plant-Microbe Interact. 5:4-13.

12. Keel, C., Weller, D. M., Natsch, A., Défago, G., Cook, R. J., and Thomashow, L. S. 1996. Conservation of the 2,4-diacetylphloroglucinol biosynthesis locus among fluorescent Pseudomonas strains from diverse geographic locations. Appl. Environ. Microbiol. 62:552-563.

13. Kempf, H.-J., Bauer, P. H., and Schroth, M. N. 1993. Herbicolin A associated with crown and roots of wheat after seed treatment with Erwinia herbicola B247. Phytopathology 83:213-216.

14. Kempf, H. J., Sinterhauf, S., Muller, M., and Pachlatko, P. 1994. Production of two antibiotics by a biocontrol bacterium in the spermosphere of barley and in the rhizosphere of cotton. Pages 114-116 in: Improving Plant Productivity with Rhizobacteria. M. H. Ryder, P. M. Stephens, and G. D. Bowen, eds., CSIRO Division of Soils, Adelaide, Australia.

15. King, E. O., Ward, M. K., and Raney, D. E. 1954. Two simple media for demonstration of pyocyanin and fluorescein. J. Lab. Clin. Med. 44:301-307.

16. Larkin, R. P., Hopkins, D. L., and Martin, F. N. 1996. Suppression of Fusarium wilt of watermelon by nonpathogenic Fusarium oxysporum and other microorganisms recovered from a disease-suppressive soil. Phytopathology 86:812-819.

17. Lindow, S. E. 1995. The use of reporter genes in the study of microbial ecology. Mol. Ecol. 4:555-566.

18. Loper, J. E., and Lindow, S. E. 1997. Reporter gene systems useful in evaluating in situ gene expression by soil- and plant-associated bacteria. Pages 482-492 in: Manual of Environmental Microbiology. C. J. Hurst, G. R. Knudsen, M. J. McInerney, L. D. Stetzenbach, and M. V. Walter, eds. ASM Press, Washington, DC.

19. Lumsden, R. D., Locke, J. C., Adkins, S. T., Walter, J. F., and Rideout, C. J. 1992. Isolation and localization of the antibiotic gliotoxin produced by Gliocladium virens from alginate prill in soil and soilless media. Phytopathology 82:230-235.

20. Maurhofer, M., Keel, C., Haas, D., and Défago, G. 1995. Influence of plant species on disease suppression by Pseudomonas fluorescens strain CHA0 with enhanced antibiotic production. Plant Pathol. 44:40-50.

21. Ownley, B. H., Weller, D. M., and Thomashow, L. S. 1992. Influence of in situ and in vitro $\mathrm{pH}$ on suppression of Gaeumannomyces graminis var. tritici by Pseudomonas fluorescens 2-79. Phytopathology 82:178-184.

22. Pierson, E. A., and Weller, D. M. 1994. Use of mixtures of fluorescent pseudomonads to suppress take-all and improve the growth of wheat. Phytopathology 84:940-947.

23. Pieterse, C. M. J., Van Wees, S. C. M., Hoffland, E., Van Pelt, J. A., and Van Loon, L. C. 1996. Systemic resistance in Arabidopsis induced by biocontrol bacteria is independent of salicylic acid accumulation and pathogenesis-related gene expression. Plant Cell 8:1225-1237.

24. Press, C. M., Wilson, M., Tuzun, S., and Kloepper, J. W. 1997. Salicylic acid produced by Serratia marcescens $90-166$ is not the primary determinant of induced systemic resistance in cucumber or tobacco. Mol. Plant-Microbe Interact. 10:761-768.

25. Raaijmakers, J. M., and Weller, D. M. 1998. Natural plant protection by 2,4-diacetylphloroglucinol-producing Pseudomonas spp. in take-all decline soils. Mol. Plant-Microbe Interact. 11:144-152.

26. Raaijmakers, J. M., Weller, D. M., and Thomashow, L. S. 1997. Frequency of antibiotic producing Pseudomonas spp. in natural environments. Appl. Environ. Microbiol. 63:881-887.

27. Sambrook, J., Fritsch, E. F., and Manniatis, T. 1989. Molecular Cloning: A Laboratory Manual, 2nd ed. Cold Spring Harbor Laboratory, Cold Spring Harbor, NY.

28. Shanahan, P., O'Sullivan, D. J., Simpson, P., Glennon, J. D., and O'Gara, F. 1992. Isolation of 2,4-diacetylphloroglucinol from a fluorescent pseudomonad and investigation of physiological parameters influencing its production. Appl. Environ. Microbiol. 58:353-358.

29. Simon, A., and Ridge, E. H. 1974. The use of ampicillin in a simplified selective medium for the isolation of fluorescent pseudomonads. J. Appl. Bacteriol. 37:459-460.

30. Slininger, P. J., and Jackson, M. A. 1992. Nutritional factors regulating growth and accumulation of phenazine-1-carboxylic acid by Pseudomonas fluorescens 2-79. Appl. Microbiol. Biotechnol. 37:388-392.

31. Thomashow, L. S., Bonsall, R. F., and Weller, D. M. 1997. Antibiotic production by soil and rhizosphere microbes in situ. Pages 493-499 in: Manual of Environmental Microbiology. C. J. Hurst, G. R. Knudsen, M. J. McInerney, L. D. Stetzenbach, and M. V. Walter, eds. ASM Press, Washington, DC.

32. Thomashow, L. S., and Weller, D. M. 1996. Current concepts in the use of introduced bacteria for biological disease control: Mechanisms and antifungal metabolites. Pages 187-236 in: Plant-Microbe Interactions, Volume 1. G. Stacey and N. T. Keen, eds. Chapman \& Hall, New York.

33. Thomashow, L. S., Weller, D. M., Bonsall, R. F., and Pierson, L. S. 1990. Production of the antibiotic phenazine-1-carboxylic acid by fluorescent Pseudomonas species in the rhizosphere of wheat. Appl. Environ. Microbiol. 56:908-912.

34. Vincent, M. N., Harrison, L. A., Brackin, J. M., Kovacevich, P. A. Murkerji, P., Weller, D. M., and Pierson, E. A. 1991. Genetic analysis of the antifungal activity of a soilborne Pseudomonas aureofaciens strain. Appl. Environ. Microbiol. 57:2928-2934.

35. Weller, D. M. 1988. Biological control of soilborne plant pathogens in the rhizosphere with bacteria. Annu. Rev. Phytopathol. 26:379-407.

36. Weller, D. M., Raaijmakers, J. M., and Thomashow, L. S. 1997. The rhizosphere ecology of antibiotic-producing pseudomonads and their role in take-all decline. Pages 58-64 in: Plant Growth-Promoting Rhizobacteria: Present Status and Future Prospects. A. Ogoshi, K. Kobayashi, Y. Homma, F. Kodama, N. Kondo, and S. Akino, eds. Kakanishi Printing, Sapporo, Japan.

37. Williams, S. T., and Vickers, J. C. 1986. The ecology of antibiotic production. Microb. Ecol. 12:43-52.

38. Wood, D. W., Gong, F., Daykin, M. M., Williams, P., and Pierson, L. S. 1997. $N$-acyl-homoserine lactone-mediated regulation of phenazine gene expression by Pseudomonas aureofaciens 30-84 in the wheat rhizosphere. J. Bacteriol. 179:7663-7670.

39. Wood, D. W., and Pierson, III, L. S. 1994. A diffusible signal molecule regulates phenazine expression in Pseudomonas aureofaciens 30-84. (Abstr.) Phytopathology 84:1082.

40. Wood, D. W., and Pierson, L. S. 1996. The phzI gene of Pseudomonas aureofaciens 30-84 is responsible for the production of a diffusible signal required for phenazine antibiotic production. Gene 168:49-53. 